\title{
Teacher Development Through Coaching and Mentoring Integrated with the 21st Century Instructional Strategies
}

\author{
Goachagorn Thipatdee ${ }^{1}$, Narat Chaichana ${ }^{1} \&$ Apirak Kamsanor $^{1}$ \\ ${ }^{1}$ Ubon Ratchathani Rajabhat University, Ubon Ratchathani, Thailand \\ Correspondence: Goachagorn Thipatdee, Ubon Ratchathani Rajabhat University, Ubon Ratchathani, Thailand.
}

Received: June 25, 2019

doi:10.5539/ies.v12n11p8
Accepted: July 28, 2019 Online Published: October 12, 2019

URL: https://doi.org/10.5539/ies.v12n11p8

\begin{abstract}
The research aimed to develop and evaluate teacher concepts and performances before and after training through coaching and mentoring procedures integrated with the $21^{\text {st }}$ century instructional strategies of project-based learning, problem-based learning, and research-based learning. The subjects were 96 teachers teaching at schools under the jurisdiction of Si Sa Ket Primary Education Office 3, Si Sa Ket Province, Thailand, purposively selected from 11 schools with lower average scores of ordinary national educational test (ONET) than those of the national level. The results revealed the teachers gained better concepts since the posttest scores were significantly higher than those of the pretest at the .01 level. The teachers' performances were at a level of pass with distinction, they satisfied with the training session at a higher level, and their composed lesson plans were at a fair level.
\end{abstract}

Keywords: teacher development, coaching and mentoring, twenty-first century instructional strategies

\section{Introduction}

Thailand has set its policy for teacher development for a long time, and it has been really practical since the national education act was established in 1999. Based on the act guidelines concerning learning processes, the aims were to develop students at their own pace to the best of their potentiality, arrange activities in line with the learners' interests and individual differences, enable the learners to think critically, provide training how to face various situations and application of knowledge for solving problems, create environment and facilities for the learners to learn and benefit from research as parts of the learning processes, and enable individuals to learn at all times and in all places (Office of the National Education Commission, 1999). Since then, Thai teachers under the jurisdiction of the Ministry of Education teaching at the basic education institutes have been expected to organize their instructions based on the student-centered methods. However, a study found teachers in central Thailand had neither clear knowledge nor experience about how to initiate such policy successfully, and how to cope with problems encountered by implementing different approaches to teaching, and felt they were left alone encountering the problems of organizing student-centered learning processes (Harn-asa, 2004). Another study found that the teachers had long been familiar with the lecture-based tradition where the teachers acted as information deliverers and the students as passive learners (Baurapha, Singh, \& Roadrangka 2006). Moreover, it was found that the teachers lacked of pedagogical content knowledge, analytical and critical thinking skills (Puengpang, Roadrangka, \& Cowie, 2007).

A research concerning student-centered approach was piloted with 9,500 teachers teaching different subjects in 90 basic education institutes through various techniques of questioning, problem solving, problem-based learning, generating of knowledge through constructivism, constructive thinking, and project-based learning. The study revealed that 3,450 students participating the pilot project, yielded positive results of improving learning behaviors, content understanding and memorization, applicability, and analytical thinking (Office of the National Education Commission, 2008). However, the results did not indicate the changes of teacher teaching behaviors across the country because Vallin and Akesson (2013) found negative results from a case study at a school in the South of Thailand that the teachers were in different stages in the development of applying student-centered teaching methods, and some teachers had much to be developed before they reached the goal.

The problems definitely affected the country educational quality, especially on the students' performance in basic education level, as empirical data released by National Institute of Educational Testing Service (2013), that the ONET results had not been satisfactory because 77,000 high school seniors taking the test had average scores of 
the assigned subjects under 50 percent, for example English at 36.99 percent, mathematics at 35.77 percent, and science at 37.46 percent. To improve the country educational quality, the very low scores of ONET must be raised, therefore, the ministry of education responsible for teacher development had set its strategies for teacher development and the project of coaching and mentoring was launched for the purposes of shifting teachers across the country from their roles of lecturers and styles of knowledge delivery to more learner-centered methods of active learning. Other instructional strategies considered to mainly focus on learners, such as project-based learning, problem-based learning, and research-based learning were integrated, so that the teachers were expected to change their roles in learning organization.

Coaching and mentoring are methods to develop people abilities in order to improve behaviors and performance as Deans, Oakley, James, and Wrigley (2006) identified the processes of coaching and mentoring are similar in that they are a series of conversations between two individuals. The definition of coaching is a short-term intervention aimed at performance improvement, while mentoring is to help and support people to manage their own learning in order to maximize their potential, develop skills, improve performance, and become what they want to be. The emphasis is quite different as coaching concerns with task, focuses on performance, agenda set by coach, addresses a short-term need, and gives feedback through discussion. On the other hand, mentoring concerns with implications, focuses on capability, agenda set by learners, addresses a longer relationship, feedback given by the learners, and discusses about intuitive issues and behaviors.

How to coach and mentor effectively is important since there are key principles, and one of those, described by Connor and Pokora (2012) is to facilitate learning and development. Teachers need to be in roles of facilitators not instructors, they need to support and challenge the students to learn and to develop. The students need to acquire new awareness, insight, skills, ideas and knowledge for learning, and they need to integrate their learning into the ways they are for developing. The teachers as facilitators need to ask good questions to provoke the students' new perspectives and changes. Another effective strategy for being good mentors is giving feedback, as McGraw and Davis (2017) concluded from research findings that feedback, especially inquiry-oriented one, enhanced students' learning, extended and deepened understanding. Through their elaborate procedures, coaching and mentoring are believed to positively affect student learning outcomes, as exemplified by research results conducted by Udintoma and Srinovita (2015), aimed to investigate the effect of coaching and mentoring programs to improve student competencies, and found that the programs improved knowledge, skills, attitudes, and competency of scholarship recipients studying at five universities. In addition, Stahl, Sharplin, and Kehrwald (2016) conducted their research to develop pre-service teachers' confidence through real-time coaching in teacher education, and found the real-time coaching model improved the pre-service teachers' sense of confidence and ownership of learning by developing practical skills, effective attributes, and disposition toward continual improvement. Moreover, coaching and mentoring are said to improve performances, as Neupane (2015) investigated the effects of coaching and mentoring on employee performance in the UK hotel industry, and concluded coaching and mentoring positively correlated to the employee performance, and both factors had significant effects on the performance.

Stepping into the $21^{\text {st }}$ century, teachers need to shift their teaching methods from lecture-based knowledge delivery to active learning styles of the student-centered to enhance students for being well prepared, as Beers (2011) concluded that educators needed to prepare students for this rapidly changing global community of today's world by providing the skills of choosing, accessing, using, and applying knowledge to innovate, solve problems, and think critically about information. The strategies of coaching and mentoring are needed to be applied through the integrating with the 21 st century methods of instruction, such as project-based learning, which is said to be an effective teaching method as Purdue University (2013) found the method increased long-term retention of learning material and improved teachers' and students' attitudes towards learning. In addition, the method affected the students' critical thinking through team work on the five-step processes of completing work bases on essential questions, presenting it to public audience, describing the challenges, decision making, and preparing the final product for real-world applications. Sole (2015) placed the project-based learning on number one of his ten hallmarks of the $21^{\text {st }}$ century teaching and learning methods as it was the primary gateway through which the hallmarks were realized. He identified the method was hands-on, collaborative, multi-disciplinary, student centered, real-time, real-world, and flexible. Renard (2017) also indicated the project-based learning was a method in which students identified a real-world problem and developed its solution, gained knowledge and skills by working for a longer period of time to investigate and respond to an engaging problem or challenge. It provided opportunities for students to use technology, promoted lifelong learning, connected them and schools with the real world, encouraged them to be more engaged, learned actively, and encouraged their imagination and creativity. Research results confirmed the above statements, as 
Kulprasutidilok (2015) investigated learning outcomes through the project-based learning of undergraduate students majoring in technology of health management, and found the students gained higher achievement, gained ability to organize the project at a very good level, and satisfied with it at the highest level. Moreover, Deejring (2016) also found her research results that the experimental group studying through the project-based learning gained higher learning achievement and creative thinking than those of the control group studying through a conventional way.

Another effective learning method of learner focus is problem-based learning since it has been widely applied throughout over four decades, beginning from the healthcare discipline and spreading through the educational fields. It is believed to develop critical thinking and creative skills, improve problem-solving skills, increase motivation, and help students learn to transfer knowledge to new situations, as Gwee (2009) concluded the method enhanced educational outcomes of learner-centered, collaborative, contextual, integrated, self-directed, and reflective learning. The instruction involved learning in small groups through social construction of knowledge using a real-life problem case to trigger the learning process. Centre for Teaching and Learning, Queen's University (2007) identified the process of learning included learners encountered a problem and attempted to solve it, identified what they needed to learn, engaged in self-directed study to research what needed and used a variety of information resources, returned to the problem and applied what they learned to their work, and assessed themselves after finishing their problem work. Research results confirmed the effectiveness of the problem-based learning, as Beringer (2007) investigated learning outcomes of the method and concluded it improved students' overall satisfaction and performances. In addition, Yew and Goh (2016) found that the method was generally consistent on demonstrating its superior efficacy for longer-term knowledge retention, and in the application of knowledge.

Research-based learning is another effective learner centered method of teaching, as Tremp (2010) stated that the method provided students with the capacity of academic thinking, promoted their education and attainment of academic expertise. The process includes formulating a general question, overview of research-literature, defining the question, planning and clarifying methodologies, undertaking investigation and analyzing data, interpretation and consideration of results, and presentation of results. Rosenshine (2012) stated the research-based learning principles of instruction consisted of beginning a lesson with a short review of previous learning, presenting new materials in small steps with student practice, asking questions and checking responses of all students, providing models, guiding student practice, checking student understanding, obtaining a high success rate, providing scaffolds for difficult tasks, requiring and monitoring independent practice, and engaging student weekly and monthly reviews. Tammachart (2009) found six attributes of the research-based learning from her research findings; they were training students for questioning and solving problem systematically, integrating various instructional techniques, encouraging the students to have important skills for learning, practicing the students' research skills through prescribed orders, using research findings together with the procedures, and stimulating the students by evaluating continuously. She also found that the experimental group had significantly higher scores of research basic knowledge, higher problem solving skills, and more desirable researcher characteristics than those of the control group at the .01 level. In addition, Parakho et al. (2010) investigated the effects of research-based learning on student nurses' learning outcomes, and found the subjects had significantly higher scores of the posttest than those of the pretest at the .01 level, gained good skills of discussion, and had positive attitude towards the learning activities at a higher level. Moreover, Srikoon and others (2014) synthesized research-based learning for education in Thailand, and concluded that the method influenced student knowledge discovery and working skills, good citizens, thinking skills, learning achievement, research characteristics, basic research skills, problem solving skills, critical thinking skills, inquiry skills, and good attitude.

According to the principles and procedures of coaching and mentoring integrated with the 21 st century instructional strategies of project-based learning, problem-based learning, and research-based learning, the teachers were expected to shift their classroom learning management to develop their students after having been trained.

\section{Method and Material}

\subsection{Research Objectives}

The study aimed to develop the teachers' concepts of coaching and mentoring, and the 21st instructional strategies of project-based learning, problem-based learning, and research-based learning through stages of training and following ups, therefore the set objectives were to 1) develop the teachers' concepts of coaching and mentoring, and the 21 st century instructional strategies of project-based learning, problem-based learning, and 
research-based learning, 2) investigate the teachers' performance throughout the training stage, 3) determine the teachers' satisfaction towards the training, and 4) evaluate the appropriateness of the teachers' lesson plans for classroom application.

\subsection{Research Design}

The study consisted of 2 stages of training and following ups, as identified:

The training stage was set for two days on 29-30 April 2013, to train the teachers concerning the concept attainment, and practice skills of coaching and mentoring, integrated with the $21^{\text {st }}$ century instructional strategies of project-based learning, problem-based learning, research-based learning, and other essential topics for learning organization. The procedures throughout the days were designed for the teachers to take a pretest individually, learn essential contents focusing on concepts and processes of 1) student potential analysis, 2) creating active learning classrooms, 3) the $21^{\text {st }}$ century skills through project-based learning, problem-based learning, and research-based learning, 4) concepts and application of coaching and mentoring, 5) concepts and application of lesson plans, and 6) creating professional learning community, through the presentation of the training staff. They were divided into small groups based on their teaching subjects of English, Thai, science, mathematics, and social studies. Each group answered questions concerning main points of the presented topics by writing answers on given paper, and practiced the expected skills together on the assigned topics for instructional demonstration [topics 3) and 4)] through planning, designing the activities, demonstrating the instruction in the context of micro teaching. The other groups took turns for the roles of coaches and mentors by asking, inquiring, suggesting, and providing feedback on the demonstration of instruction. At the end of the second day training, the teachers took a posttest individually. Before breaking up the training, the school principals, the supervisors, and the teachers made appointments for the following ups and the school visits from the researchers to evaluate the teacher performance which needed to be done within the end of August 2013.

The second stage of the following ups by the school principals, and the supervisors needed to be done within the end of July 2013, and then the researchers visited the schools for teacher evaluation within August 2013. The school visits set for four days at four school-network centers, the teachers of each school were appointed to report about their real classroom performance then the school principals, the supervisors provided additional information before the researchers provided feedback. Each teacher submitted a lesson plan based on coaching and mentoring integrated with project-based learning, problem-based learning, and research-based learning. The 11 school principals, and the supervisors responsible for those schools, were coordinators and also evaluators for the follow-up stages.

\subsection{Population and Sampling Procedures}

The sample of 96 teachers teaching in 11 schools was purposively selected based on the lower test scores of the school students on the ONET than those of the national averages, therefore the 11 schools were named as Anuban Phusing School, Ban Tameng School, Ban Wanasawan School, Ban Khayoong School, Ban Pongkok School, Ban Huachang School, Ban Koo School, Ban Samkha School, Ban Tarangsawai School, Swongpatanasuksa School, and Ban Huisaphoom School. The average scores of the ONET at the national level in five subjects of mathematics, the Thai language, social studies, science, and English were 35.77, 45.68, 44.22, 37.46, 36.99 percent respectively, while those of the 11 schools were 30.87, 41.95, 40.56, 34.39, and 30.38. All of the students studying at 2 schools (Ban Koo School and Ban Samkha School) located in Prankoo District speaking the Kuy dialect in their daily life, and the rests studying at 9 schools speaking the Khmer language.

\subsection{Instruments}

The instruments consisted of four different types as identified:

1) A cognitive test of four-multiple choices with 30 items used for the pretest and the posttest, the contents of the test mainly focused on concepts and application of coaching and mentoring, the 21 st century instructional strategies of project-based learning, problem-based learning, and research-based learning. The test made by the training staff, and validated by senior lecturers instructing at the Faculty of Education, Ubon Ratchathani Rajabhat University. The total score of the test was 15 , and the analysis of mean score difference between the pretest and the posttest made by employing t-test.

2) An activity scoring record was applied to score the teachers' performance while having been trained. The activities included 6 topics as identified above. The performance evaluation criteria were based on Borich (1994) as identified scores of 80-100 percent mean pass with distinction, the scores of 50-79.99 percent mean pass, and the scores of 1-49.99 percent mean fail.

3) A five-point Likert scale of evaluation form for training satisfaction consisted of twenty-two items in four 
aspects of content appropriateness with three items, the training organization with eight items, the presentation of the training staff with six items, and the project usefulness with five items. The evaluation criteria of average scores $(\bar{x})$ were set as 4.50-5.00 mean the highest, 3.50-4.49 mean higher, 2.50-3.49 mean medium, 1.50-2.49 mean lower, and 1.00-1.49 mean the lowest.

4) A three-point Likert scale of evaluation form for the lesson plans consisted of sixteen items through three steps of preparation on four items, the presentation and practice on ten items, and the conclusion on two items. The evaluation criteria of average scores $(\bar{x})$ were set as 2.50-3.00 mean good, 1.50-2.49 mean fair, and 1.00-1.49 mean weak.

\section{Results}

The research findings were described based on the objectives as follows;

1) The teachers gained better concepts compared between the pretest and the posttest scores, with the $t$ value of 5.80 indicated the significant difference at the .01 level, as displayed in Table 1.

Table 1. The concept scores of pretest and posttest, and the scores of activity performance

\begin{tabular}{|c|c|c|c|c|c|c|c|c|c|c|c|c|c|}
\hline 1.Concepts & $\bar{x}$ & SD. & \multicolumn{11}{|c|}{ t-test values } \\
\hline Pretest & 5.62 & 2.29 & \multirow{2}{*}{\multicolumn{11}{|c|}{$5.80 * *$}} \\
\hline Posttest & 6.90 & 2.60 & & & & & & & & & & & \\
\hline \multirow{3}{*}{$\begin{array}{l}\text { 2.Activity } \\
\text { performance }\end{array}$} & \multicolumn{2}{|c|}{$\begin{array}{c}\text { Activity } 1 \\
\text { total10 }\end{array}$} & \multicolumn{2}{|c|}{$\begin{array}{c}\text { Activity } 2 \\
\text { total15 }\end{array}$} & \multicolumn{2}{|c|}{$\begin{array}{c}\text { Activity } 3 \\
\text { total15 }\end{array}$} & \multicolumn{2}{|c|}{$\begin{array}{c}\text { Activity } 4 \\
\text { total15 }\end{array}$} & \multicolumn{2}{|c|}{$\begin{array}{c}\text { Activity } 5 \\
\text { total15 }\end{array}$} & \multicolumn{2}{|c|}{$\begin{array}{c}\text { Activity } 6 \\
\text { total15 }\end{array}$} & Total $\bar{x}$ score \\
\hline & $\bar{x}$ & SD. & $\bar{x}$ & SD. & $\bar{x}$ & SD. & $\bar{x}$ & SD. & $\bar{x}$ & SD. & $\bar{x}$ & SD. & 72.32 \\
\hline & 7.61 & 2.22 & 13.13 & 2.34 & 13.64 & 2.37 & 14.31 & 2.58 & 10.33 & 2.93 & 13.28 & 2.44 & $(85.08 \%)$ \\
\hline
\end{tabular}

$* * \mathrm{p} \leq .01$.

2) The teacher performance was considered as pass with distinction since the average scores of all 6 activities were 72.32, which was at 85.08 percent, as also displayed in table 1.

3) The teachers satisfied with the training stage in all aspects of content appropriateness, training organization, presentation of the training staff, and training usefulness, at a higher level with the average scores ranged 3.50-4.49, as displayed in Table 2. They also suggested the training project was useful and should have been disseminated to other schools located in the province. 
Table 2. The teachers' satisfaction towards the training stage

\begin{tabular}{|c|c|c|c|c|}
\hline \multirow{2}{*}{ Item } & \multirow{2}{*}{ List of satisfaction items } & \multicolumn{3}{|c|}{ Level of satisfaction } \\
\hline & & $\bar{x}$ & SD. & Meaning \\
\hline 1 & The aspect of content appropriateness & & & \\
\hline 1.1 & The contents are appropriately designed. & 3.83 & .56 & higher \\
\hline 1.2 & The contents are appropriately arranged. & 3.89 & .59 & higher \\
\hline 1.3 & The contents in provided handouts are clear and concise. & 3.86 & .68 & higher \\
\hline 2 & The aspect of training organization & & & \\
\hline 2.1 & The reception and hospitality of the liaisons is appropriate. & 4.18 & .56 & higher \\
\hline 2.2 & The registration is well organized. & 4.13 & .49 & higher \\
\hline 2.3 & The duration and time of training is set appropriately. & 3.71 & .80 & higher \\
\hline 2.4 & The training venue is comfortable. & 4.13 & .66 & higher \\
\hline 2.5 & The training atmosphere is positively motivated. & 4.31 & .62 & higher \\
\hline 2.6 & The convenience through training is appropriate. & 4.20 & .62 & higher \\
\hline 2.7 & The provided audio materials are appropriate. & 4.01 & .63 & higher \\
\hline 2.8 & The meals and beverages are appropriate. & 4.27 & .59 & higher \\
\hline 3 & The aspect of the training staff presentation & & & \\
\hline 3.1 & The presentation of student potential analysis & 3.92 & .63 & higher \\
\hline 3.2 & The presentation of creating active learning classrooms & 3.95 & .70 & higher \\
\hline 3.3 & The presentation of $21^{\text {st }}$ century skills through PBLs and RBL & 3.96 & .61 & higher \\
\hline 3.4 & The concepts and application of coaching and mentoring & 3.92 & .59 & higher \\
\hline 3.5 & The concepts and application of lesson plans & 3.92 & .63 & higher \\
\hline 3.6 & The creating professional learning community & 3.80 & .68 & higher \\
\hline 4 & The aspect of training usefulness & & & \\
\hline 4.1 & Gain content concepts and guidelines of application & 3.65 & .65 & higher \\
\hline 4.2 & Be confident to apply the gained concepts in real classrooms & 3.59 & .68 & higher \\
\hline 4.3 & Be confident to coach and mentor effectively & 3.54 & .59 & higher \\
\hline 4.4 & Be confident that the training is useful for student achievement & 3.59 & .63 & higher \\
\hline 4.5 & Be confident that the training enhances learning community & 3.68 & .61 & higher \\
\hline
\end{tabular}

4) The teachers composed appropriate lesson plans based on coaching and mentoring integrated with the $21 \mathrm{st}$ century instructional strategies of project-based learning, problem-based learning, and research-based learning, and was considered as pass since the average scores of every item met the minimum criterion of 1.50 at a fair level. However, there was no written data of 3 schools reported by the principles, and 5 schools by the supervisors, as displayed in Table 3.

Table 3. The teachers' lesson plan compositions

\begin{tabular}{|c|c|c|c|c|c|c|c|c|c|c|}
\hline \multirow{2}{*}{ Item } & \multirow{2}{*}{ Schools } & \multicolumn{3}{|c|}{ Principals } & \multicolumn{3}{|c|}{ Supervisors } & \multicolumn{3}{|c|}{ Researchers } \\
\hline & & $\bar{x}$ & SD. & Meaning & $\bar{x}$ & SD. & Meaning & $\bar{x}$ & SD. & Meaning \\
\hline 1 & Anuban Phusing School & 2.38 & .48 & Fair & 2.69 & .41 & Good & 2.93 & .10 & Good \\
\hline 2 & Ban Tameng School & 2.42 & .55 & Fair & 2.63 & .48 & Good & 2.26 & .46 & Fair \\
\hline 3 & Ban Wanasawan School & - & - & - & - & - & - & 2.26 & .46 & Fair \\
\hline 4 & Ban Khayoong School & 2.51 & .45 & Good & - & - & - & 2.66 & .57 & Good \\
\hline 5 & Ban Pongkok School & - & - & - & 2.63 & .46 & Good & 2.26 & .46 & Fair \\
\hline 6 & Ban Huachang School & 2.65 & .37 & Good & - & - & - & 1.95 & .94 & Fair \\
\hline 7 & Ban Koo School & 2.07 & .23 & Fair & - & - & - & 1.93 & .91 & Fair \\
\hline 8 & Ban Samkha School & - & - & - & - & - & - & 2.66 & .57 & Good \\
\hline 9 & Ban Tarangsawai School & 2.50 & .47 & Good & 2.16 & .55 & Fair & 3.00 & .00 & Good \\
\hline 10 & Swongpatanasuksa School & 2.51 & .45 & Good & 2.54 & .39 & Good & 2.66 & .57 & Good \\
\hline 11 & Ban Huisaphoom School & 2.39 & .37 & Fair & 2.39 & .45 & Fair & 2.95 & .07 & Good \\
\hline
\end{tabular}

\section{Discussion}

According to the first research objective, the result indicated the teachers gained better concepts of coaching and mentoring integrated with the $21^{\text {st }}$ century instructional strategies of project-based learning, problem-based 
learning, and research-based learning by comparing the pretest and the posttest scores, with $\mathrm{t}$ value of 5.80 , showed significant difference at the .01 level. This might have been because the training activities were learner-centered, or emphasized on active learning since the group members cooperatively planned on the assigned topics, designed the learning activities, demonstrated the instruction, and the other groups took turns for the roles of coaches and mentors for reflections. The activities related to principle stated by Prince (2004) that active learning was any instructional method that engaged students in the learning process, it required students to do meaningful learning activities and thought about what they were doing. The finding implied that the teachers needed to learn various learning activities and change their teaching behaviors to be more learner-centered, and more active learning focus because these can positively affected the students' learning outcomes, as confirmed by Taraban, Box, Myers, Pollard, and Bowen (2007) that active learning significantly helped students gain better content knowledge, and knowledge of process skills using the labs than those learning through traditional instruction. In addition, Chiu and Cheng (2017) concluded that lessons designed through active learning were better in encouraging student creativity and innovation than those with regular learning. They also concluded that active learning classrooms were better environment for nurturing innovation for all students, regardless of their academic ability.

The teachers were considered as pass with distinction for the activity performance since the average scores of 6 activities were 72.32 out of 85 , which was at 85.08 percent. This might have been because the training was focusing on small group performance, and learning procedures were based on active learning, which was a core component of collaborative learning, cooperative learning, and problem-based learning (Prince, 2004). The finding was related to research results conducted on the procedures of cooperative learning in small groups which members interact to each other, such as Batool (2012), studied the effect of cooperative learning on achievement, Altun (2015) studied the effect of cooperative learning on students' achievement, and Parveen, Yousuf, and Mustafa (2017) studied the effect of cooperative learning on students' academic achievement, which found similar findings that cooperative learning showed better results for student scholastic accomplishment. Moreover, Tandogan and Orhan (2007) studied the effects of problem-based active learning in science education on students' academic achievement, and found that the subjects gained positively academic achievement and conceptual development, and had misconceptions in science education at the lowest level. The finding and the supporting research results implied good signs for the teachers to apply more learner-centered learning activities.

The teachers' satisfaction towards the training stages was at a higher level on every item with the average scores ranged 3.50-4.49, which was positively congruent to the average scores they got through the training, judged as pass with distinction at the percentage of 85.08. The result indicated the active learning activities set for the teachers to involve, interact, demonstrate the group assignments, and reflect the other group performance as coaches and mentors, positively affected their satisfaction. The result related to the findings revealed by Roh, Lee, and Mennenga (2014), as they studied factors influencing learner satisfaction with team-based learning among nursing students, and the result released by Hynn, Ediger, and Lee (2017), as they studied the effect of active learning on satisfaction, which similarly revealed that active learning activities increased students' satisfaction. Moreover, Carlson and Winquist (2011) evaluated an active learning approach to teaching introductory statistics, and Dilmac (2016) studied the effect of active learning techniques on class teacher candidates' success rates, and found similar results that the subjects gained significantly academic achievement, and positive attitude. The teachers also suggested the project was useful and should have been disseminated to other schools located in the province where students spoke other languages of Kuy and Khmer since they faced problems in teaching the students speaking different languages, and recognized their inferior in academic performance, which confirmed by Hagen (1989), Adger, Wolfram, and Detwyler (1993), that dialect speakers negatively affected, or were at disadvantages in their education. Moreover, Mohammed (2002) found that not only students, but also teachers faced barriers in teaching due to dialect and cultural differences.

The teachers' lesson plan compositions were evaluated as pass, determined by the minimum mean score of 1.50 , at a fair level. This showed the teachers applied the project-based learning, problem-based learning, and research-based learning instructional strategies, and improved their performance in their classroom instruction. This might have been because the teachers learned how to construct learning activities based on the active learning approach for the purposes of changing their teaching styles and improving the students' learning outcomes. The finding related to the results found by Taraban, Box, Myers, Pollard, and Bowen (2007) that teachers who used active learning through the lab-based, perceived changing their behaviors as intended by the student-centered principles. Therefore, it is sound to conclude that after the teachers have gained significant concepts of coaching and mentoring integrated with the 21 st century instructional strategies of project-based learning, problem-based learning, and research-based learning, and had positive attitude towards the training, 
improved their lesson plans.

\section{Conclusion}

The development and evaluation of teachers' concepts and performance after training through coaching and mentoring procedures integrated with the 21 st century instructional strategies of project-based learning, problem-based learning, and research-based learning, indicated 96 teachers participating the training project, gained better concepts, performed sufficient skills for their real classroom application, and expressed positive satisfaction towards the training. The teachers also composed fair lesson plans for their students' academic enhancement. These are good signs for Thai teachers to initiate the ideas of active learning pedagogies to their real classrooms for the purposes of increasing the students' learning achievement, performance, and satisfaction.

\section{Acknowledgements}

Grateful thanks to the Faculty of Education for supporting the research budget, the teachers of Si Sa Ket Primary Education Office 3 for collaboration in the training, informative report about classroom performance, and submission of lesson plans. Special thanks to the school principals, and the supervisors for warm welcome and school visits, co-ordination, and provision of transportation.

\section{References}

Adger, C., Wolfram, M., \& Detwyler, J. (1993). Confronting Dialect Minority Issues in Special Education: Reactive and Proactive Perspectives. Third National Research Symposium on Limited English Proficient Students: Focus on Middle and High School Issues.

Altun, S. (2015). The Effect of Cooperative Learning on Students' Achievement and Views on Science and Technology Course. International Electronic Journal of Elementary Education, 7(3), 451-468.

Batool, S. (2012). Effect of Cooperative Learning on Achievement of Students in General Science at Secondary Level. International Education Studies, 5(2), 154-158. https://doi.org/10.5539/ies.v5n2p154

Baurapha, K., Singh, P., \& Roadrangka, V. (2006). Teaching, Learning and Conceptual Development of Force and Motion in Third-year Preservice Physics Teachers. The Journal of Behavioral Science, 1(1), 62-66.

Beers, S. Z. (2011). Teaching 21st Century Skills. Alexandria: ASCD.

Beringer, J. (2007). Application of Problem Based Learning through Research Investigation. Journal of Geography in Higher Education, 31(3), 445-457. https://doi.org/10.1080/03098260701514033

Borich, G. D. (1994). Observation Skills for Effective Teaching. New York: Macmillan Publishing Company.

Carlson, K. A., \& Winquist, J. R. (2011). Evaluating an Active Learning Approach to Teaching Introductory Statistics: A Classroom Workbook Approach. Journal of Statistics Education, 19(1), 1-22. https://doi.org/10.1080/10691898.2011.11889596

Centre for Teaching and Learning, Queen's University. (2007). Problem-Based Learning. Kingston: Queen's University.

Chiu, P. H. P., \& Cheng, S. H. (2017). Effects of Active Learning Classrooms on Student Learning: A Two-year Empirical Investigation on Student Perceptions and Academic Performance. Higher Education Research \& Development, 36(2), 269-279. https://doi.org/10.1080/07294360.2016.1196475

Deans, F., Oakley, L., James, R., \& Wrigley, R. (2006). Coaching and Mentoring for Leadership Development in Civil Society. Oxford: INTRAC.

Deejring, K. (2016). Knowledge Management to Develop Creative Thinking for Higher Education with Project-based Learning. A Research Report. Nakhonrachasima Rajabhat University.

Dilmac, O. (2016). The Effect of Active Learning Techniques on Class Teacher Candidates' Success Rates and Attitudes toward Their Museum Theory and Application Unit in Their Visual Arts Course. Educational Sciences: Theory and Practice, 16(5), 1587-1618. https://doi.org/10.12738/estp.2016.5.0108

Gwee, M. C.-E. (2009). Problem-based Learning: A Strategic Learning System Design for the Education of Healthcare Professionals in the 21st Century. Kaohsiung Journal of Medical Science, 25(5), 231-239. https://doi.org/10.1016/S1607-551X(09)70067-1

Hagen, A. (1989). Dialect, Frisian and Education in the Netherlands. Dialect and Education: Some European Perspectives (pp. 48-61). Philadelphia: Multilingual Maters Ltd.

Harn-asa, P. (2004). The Implementation of the Instructional Reform Policy in Thai Public Secondary Schools: 
Case Studies. A Dissertation Submitted in Partial Fulfillment of the Requirements for the Degree Doctor of Education. Faculty of Education and Social Work, The University of Sydney.

Hynn, J., Ediger, R., \& Lee, D. (2017). Students' Satisfaction on Their Learning Process in Active Learning and Traditional Classrooms. International Journal of Teaching and Learning in Higher Education, 29(1), 108-118.

Kulprasutidilok, A. (2015). Project-based Learning in Home Health Care of First Aids, Home Health Care Emergency System for Technology of Health Management Students Level 2. Research Report. Phranakorn Rajabhat University.

McGraw, A., \& Davis, R. (2017). Mentoring for Pre-service Teachers and the Use of Inquiry-oriented Feedback. International Journal of Mentoring and Coaching in Education, 6(1), 50-63. https://doi.org/10.1108/IJMCE-03-2016-0023

Mohammed, T. (2002). An Exploration of Students' and Teachers' Attitude towards Ebonics in a Community College Writing Program. ERIC Database (Ed 479490).

National Institute of Educational Testing Service. (2013). 2013 ONET Results. Retrieved from https://teen.mthai.com/education

Neupane, R. (2015). Effects of Coaching and Mentoring on Employee Performance in the UK Hotel Industry. International Journal of Social Sciences and Management, 2(2), 123-138. https://doi.org/10.3126/ijssm.v2i2.12323

Office of the National Education Commission. (1999). National Education Act of B.E. 2542 (1999).

Office of the National Education Commission. (2008). Education in Thailand 2007. Bangkok, Amarin Printing and Publishing.

Parakho, P., Kurat, S., Imnamkhao, S., Boranmoon, G., Anseekaew, M., Kor-issaranuphab, N., \& Chainrum, S. (2010). The Effects of Research-Based Learning on the Learning Achievements in the Course of Nursing of Persons with Health Problem 2, Srimahasarakham Nursing College. Research Report. Srimahasarakham Nursing College, Mahasarakham.

Parveen, Q., Yousuf, M. I., \& Mustafa, S. (2017). An Experimental Study on the Effect of Cooperative Learning on Students' Academic Achievement and Students' Perceptions towards Cooperative Learning. The Anthropologist, 27(1-3), 69-76. https://doi.org/10.1080/09720073.2017.1311670

Prince, M. (2004). Does Active Learning Work? A Review of the Research. Journal of Engineering Education, 93(3), 223-231. https://doi.org/10.1002/j.2168-9830.2004.tb00809.x

Puengpang, N., Roadrangka, V., \& Cowie, B. (2007). Development of an Instructional Set for a Laboratory in Biology Course for First-year Thai Science Student Teachers. CMU Journal of Science of Social Science and Humanities, 1(1), 119-135.

Purdue University. (2013). The PBL Model. Retrieved from https://www.noodle.com

Renard, L. (2017). What is project-based learning? 15 PBL ideas fit for your classroom. Retrieved from https://www.bookwidgets.com/

Roh, Y. S., Lee, S. J., \& Mennenga, H. (2014). Factors Influencing Learner Satisfaction with Team-based Learning among Nursing Students. Nursing and Health Sciences, 16, 490-497. https://doi.org/10.1111/nhs.12118

Rosenshine, B. (2012). Principles of Instruction: Research-Based Strategies That All Teachers Should Know. American educator, 36(1), 12.

Sole, J. (2015). 10 Hallmarks of 21st Century Teaching and Learning. Retrieved from https://www.edutopia.org/discussion/10-hallmarks-21st-century-teaching-and-learning

Srikoon, S., Bunterm, T., Samranjai, J., \& Wattanathorn, J. (2014). Research synthesis of research-based learning for education in Thailand. Procedia-Social and Behavioral Sciences, 116, 913-917. https://doi.org/10.1016/j.sbspro.2014.01.319

Stahl, G., Sharplin, E., \& Kehrwald, B. (2016). Developing Pre-service Teachers' Confidence: Real-time Coaching in Teacher Education. Reflective Practice, 17(6), 724-738. https://doi.org/10.1080/14623943.2016.1206882

Tammachart, J. (2009). A Research and Development of Research-Based Learning Management Model in the 
Educational Research Course. Research Report. Prince of Songkla University, Pattani Campus, Pattani.

Tandogan, R. O., \& Orhan, A. (2007). The Effects of Problem-Based Active Learning in Science Education on Students' Academic Achievement, Attitude and Concept Learning. EURASIA Journal of Mathematics, Science and Technology Education, 3(1), 71-81. https://doi.org/10.12973/ejmste/75375

Taraban, R., Box, C., Myers, R., Pollard, R., \& Bowen, C. W. (2007). Effects of active-learning experiences on achievement, attitudes, and behaviors in high school biology. Journal of Research in Science Teaching, 44(7), 960-979. https://doi.org/10.1002/tea.20183

Tremp, P. (2010). Research-based Teaching and Learning: A LERU Project. Munich: University of Zurich, Center for University Teaching and Learning.

Udintoma, P., \& Srinovita, Y. (2015). The Effect of Coaching and Mentoring Programs to Improve Students Competencies: Case Study of Beastudi Etos Scholarship. Horizon Research Publishing. https://doi.org/10.13189/ujer.2015.030302

Vallin, M., \& Akesson, S. (2013). Learning Environment in Thailand: A Case Study Regarding Teaching Methods and Motivation in a Thai School. Retrieved from https://www.diva-portal.se/smash/get/diva2:603432/FULLTEXT01.pdf

Yew, E. H. J., \& Goh, K. (2016). Problem-Based Learning: An Overview of its Process and Impact on Learning. Health Professions Education, 2(2), 75-79. https://doi.org/10.1016/j.hpe.2016.01.004

\section{Copyrights}

Copyright for this article is retained by the author(s), with first publication rights granted to the journal.

This is an open-access article distributed under the terms and conditions of the Creative Commons Attribution license (http://creativecommons.org/licenses/by/4.0/). 